\title{
Carbon sources supporting a diverse fish community in a tropical coastal ecosystem (Gazi Bay, Kenya)
}

\author{
J. Nyunja ${ }^{\text {a,c,* }}$, M. Ntiba ${ }^{\text {a }}$, J. Onyari ${ }^{\text {b }}$, K. Mavuti ${ }^{\text {a }}$, K. Soetaert ${ }^{\text {d }}$, S. Bouillon ${ }^{\text {d,e,1 }}$ \\ a School of Biological Sciences, University of Nairobi, P.O. Box 30197, 00100 Nairobi, Kenya \\ ${ }^{\mathrm{b}}$ School of Physical Sciences, University of Nairobi, P.O. Box 30197, 00100 Nairobi, Kenya \\ ${ }^{\mathrm{c}}$ Kenya Wildlife Service, P.O. Box 40241, 00100 Nairobi, Kenya \\ ${ }^{\mathrm{d}}$ Netherlands Institute of Ecology, Centre for Estuarine and Marine Ecology (NIOO-KNAW), P.O. Box 140, 4400 AC Yerseke, The Netherlands \\ ${ }^{\mathrm{e}}$ Department of Analytical and Environmental Chemistry, Vrije Universiteit Brussel, Pleinlaan 2, B-1050 Brussels, Belgium
}

\section{A R T I C L E I N F O}

\section{Article history:}

Received 26 February 2008

Accepted 5 January 2009

Available online 19 January 2009

\section{Keywords:}

mangroves

seagrasses

fish

stable isotopes

food webs

Gazi Bay

\begin{abstract}
A B S T R A C T
Interlinked mangrove-seagrass ecosystems are characteristic features of many tropical coastal areas, where they act as feeding and nursery grounds for a variety of fishes and invertebrates. The autotrophic carbon sources supporting fisheries in Gazi bay (Kenya) were studied in three sites, two located in the tidal creeks flowing through extensive mangrove forests, another site located in the subtidal seagrass meadows, approximately $2.5 \mathrm{~km}$ away from the forest. Carbon and nitrogen stable isotope composition of 42 fish species, 2 crustacean species and a range of potential primary food sources (e.g., mangroves, seagrasses and epiphytes, macroalgae) were analysed. There was considerable overlap in the $\delta^{13} \mathrm{C}$ signatures between fish $(-16.1 \pm 2.1 \%$ o $)$, seagrasses $(-15.1 \pm 3.0 \%$ o $)$, seagrass epiphytes $(-13.6 \pm 3.3 \%$, and macroalgae $(-20.4 \pm 3.1 \%$ ). Nevertheless, the signatures for most primary producers were sufficiently distinct to indicate that the dominant carbon sources for fish were mainly derived from the seagrass and their associated epiphytic community, and possibly macroalgae. Mangrove-derived organic matter contributes only marginally to the overall fish food web. Carbon supporting these fish communities was derived directly through grazing by herbivorous and some omnivorous fishes, or indirectly through the benthic food web. Fishes from the mangrove creeks had distinctly lower $\delta^{13} \mathrm{C}$ signatures $(-16.8 \pm 2.0 \%$ o compared to those collected in the adjacent seagrass beds $(-14.7 \pm 1.7 \%)$. This indicated that these habitats were used as distinct sheltering and feeding zones for the fishes collected, with minimal degree of exchange within the fish communities despite their regular movement pattern.
\end{abstract}

(c) 2009 Elsevier Ltd. All rights reserved.

\section{Introduction}

Coastal bays and mangrove-fringed estuaries are productive ecosystems, supporting a diversity of habitats, complex species interactions, and they are often characterized by a high degree of nutrients and organic matter exchange. These ecosystems are known to provide shelter and nursery grounds for fish and other organisms (Chong et al., 1990; Nagelkerken and van der Velde, 2004a; Nagelkerken et al., 2008). The diversity and structural complexity in these habitats provide multiple spatial and trophic niches available for juvenile fishes (Baran and Hambrey, 1998).

\footnotetext{
* Corresponding author. School of Biological Sciences, University of Nairobi, P.O. Box 30197, 00100 Nairobi, Kenya

E-mail addresses: jnyunja@kws.go.ke, jnyunja@yahoo.com (J. Nyunja).

1 Present address: K.U. Leuven, Department of Earth \& Environmental Sciences, Kasteelpark 20, B-3000 Leuven, Belgium.
}

Carbon from mangrove ecosystems can be exported in the form of detritus, leaves, particulate organic carbon (POC), dissolved organic carbon (DOC), and dissolved inorganic carbon (DIC) to adjacent ecosystems; although usually only a few kilometers away into the open waters (Hemminga et al., 1994; Lee, 1995). Further, studies reported that mangrove forests and seagrass meadows produce excess carbon that is not entirely used by consumers in the ecosystem, but $\sim 40 \%$ of the photosynthetic carbon is exported out of the system or stored in the sediment (Duarte and Cebrian, 1996). The exported material may be used in the detrital food web in adjacent habitats (Connolly et al., 2005), although there is still limited unambiguous evidence for such a role for mangrovederived material (Bouillon et al., 2008). A review of literature demonstrating the dependence of fish harvests on estuarine environments shows the importance of these systems in terms of sustainable management of the coastal resources (Baran and Hambrey, 1998). Similarly, various studies have shown a positive relationship between mangrove area coverage and coastal fishery 
catches (Pauly and Ingles, 1986; Paw and Chua, 1989), although the causal links are likely to be much more complex than the mere presence and extent of mangrove vegetation (Meynecke et al., 2007). One of the possible links between these ecosystems and secondary productivity is the provision of abundant food sources. Therefore, understanding the functional relationship between fisheries productivity and coastal wetlands through investigating their trophic support is quite useful for fisheries management.

In this context, there is still need to understand the role of various autotrophs in mangrove ecosystems. This is possible through elaborate studies establishing trophic fluxes, assimilation efficiencies, energy transfer and dissipation. However, determination of the relative importance of organic carbon sources to consumer productivity in estuarine ecosystems is complicated by the spatial complexity of the system, variations in organic matter exchange, and availability of multiple potential organic matter sources (Deegan and Garritt, 1997). The multitude of sources and types of organic matter entering food webs presents challenges to quantitative analysis of the relative importance of each source. A potentially useful approach to elucidate the role of autotrophs in aquatic food webs is the application of stable isotope analysis (SIA), which has become increasingly popular in recent years.

Generally, different autotrophs have distinct chemical and isotopic compositions. Studies show that terrestrial plants including salt marsh plants contain high content of macromolecules with low $\mathrm{N}$ content such as lignin, tannin, hemicellulose, cellulose, cutin, and suberin, and have higher $\mathrm{C} / \mathrm{N}$ ratios ranging between 20 and 500 compared to marine plankton $(\sim 7)$ (Hedges et al., 1997). Moreover, terrestrial vascular plants using the C3 photosynthetic pathway are more depleted in ${ }^{13} \mathrm{C}\left(\delta^{13} \mathrm{C}\right.$ generally between $-31 \%$ and $-26 \%$ ) than C4 salt marsh plants $(-16 \%$ to $-12 \%$ ) (Fry and Sherr, 1984), while oceanic phytoplankton has an intermediate $\delta^{13} \mathrm{C}$ values $(\sim-21 \%$ o. Therefore, SIA offers the ability to assess different sources of organic matter, energy flow and feeding relationships in marine ecosystems (Minagawa and Wada, 1984; Hobson and Welch, 1992; Marguillier et al., 1997). Generally, carbon isotopes offer insights into the sources of organic matter for consumers, whereas nitrogen isotopes can indicate trophic levels (Peterson and Fry, 1987; McCutchan et al., 2003). SIA provides more information regarding the assimilated diet of aquatic organisms over long period than conventional gut content analysis, although it cannot offer the same taxonomic resolution.

Diet and habitat use by aquatic organisms can be determined through isotopic analysis of various tissue types which have different turnover times, while linking their isotopic values to specific food or habitat types. Higher turnover rates are found in metabolically active tissues such as the liver and the heart as compared to muscle tissue (Tieszen et al., 1983; Hobson and Clark, 1992; Logan et al., 2006). Guelinckx et al. (2007), for example reported in the tissues of an estuarine goby half-lives for $\delta^{13} \mathrm{C}$ and $\delta^{15} \mathrm{~N}$ turnover in muscle tissue to be approximately 25 and 28 days respectively, while the shortest half-life value for $\delta^{15} \mathrm{~N}$ was in liver tissue ( 3 days) and for $\delta^{13} \mathrm{C}$ in the heart tissue ( 6 days). Therefore, short-term and long-term diet can be determined through isotopic analysis of the liver and muscle tissues respectively.

Use of $\delta^{13} \mathrm{C}$ and $\delta^{15} \mathrm{~N}$ to infer organic matter sources and trophic levels has widely been accepted. With each trophic transfer between a consumer and its diet, $\delta^{13} \mathrm{C}$ increases by on average $0-1 \%$ (Fry and Sherr, 1984), whereas $\delta^{15} \mathrm{~N}$ is typically cited to increase by $\sim 3.4 \%$ per trophic level (Minagawa and Wada, 1984). Recent studies, however, indicate that variation in enrichment of $\delta^{15} \mathrm{~N}$ values between diet and consumers ranges quite widely (Vander Zanden and Rasmussen, 2001; Vanderklift and Ponsard, 2003), and is dependent on processes of nitrogen assimilation and excretion by consumers. According to the data compiled by McCutchan et al.
(2003), the average shift in $\delta^{15} \mathrm{~N}$ for consumers raised on plants and algal diet is $2.2 \pm 0.3 \%$, and even lower $(1.4 \pm 0.2 \%$ ) for species with a predominantly invertebrate-based diet.

Various potential primary food sources for fish in marine systems (e.g., mangroves, seagrasses, macroalgae, epiphytes, microphytobenthos, and phytoplankton) have different, though in some cases overlapping, isotopic signatures. Mangroves and seagrass $\delta^{13} \mathrm{C}$ do not overlap (Bouillon et al., 2008); and for seagrasses, a clear gradient in $\delta^{13} \mathrm{C}$ from sites close to mangroves towards coral reef areas has been reported in Gazi Bay, due to a distinct gradient in the $\delta^{13} \mathrm{C}$ of dissolved inorganic carbon (DIC) (Hemminga et al., 1994; Bouillon et al., 2007). Therefore, stable carbon analysis offer a promising approach to show the relative contributions of various primary carbon sources to consumers in this ecosystem, and to distinguish the role of mangrove and seagrass habitats as feeding grounds for mobile fauna such as fish.

The function of mangrove ecosystems in providing food and protective habitat for fishes has widely been studied through stable isotopes analysis, gut content analysis and observational evidence (Chong et al., 1990; Nagelkerken and van der Velde, 2004b; Lugendo et al., 2006, 2007; Blaber, 2007; Nagelkerken et al., 2008). The trophic organization of fish fauna in Gazi Bay has also been a subject of some previous studies (De Troch et al., 1996; Kimani et al., 1996; Marguillier et al., 1997), although the species considered did not represent the diverse fish community found in this bay.

Gazi Bay is characterized by frequent tidal fluctuations which expose large intertidal areas of the Bay. Thus the need for fish to adopt strategies that enable their movement and occupation of alternative habitats; to optimize the trade-off between food acquisition and predator avoidance over the full range of tidal conditions (Sogard, 1992; Sheaves, 2005). Such daily tidal variations and fish movement allow for continuous biological connectivity between mangrove and seagrass habitats, which simultaneously link food webs in these different habitats. Hence, understanding trophic relationships, life-history strategies, community patterns should be set in a spatial context. The aims of this study were therefore twofold: (1) to determine the main primary carbon sources supporting the diverse fish community of the mangrove creeks and adjacent seagrass beds of Gazi bay; and (2) to examine the extent to which adjacent mangroves and seagrass beds act as separate feeding habitats.

\section{Materials and methods}

\subsection{Description of study site}

Gazi Bay (Fig. 1) is located about $50 \mathrm{~km}$ south of Mombasa on the Kenyan coast $\left(4^{\circ} 25^{\prime} \mathrm{S}, 39^{\circ} 30^{\prime} \mathrm{E}\right)$. The bay is a tropical lagoon with a fringing coral reef at the seaward side, and extensive seagrass beds in between the mangrove forest and the reefs (Hemminga et al., 1994). The intertidal and subtidal areas are covered by several species of seagrass interspersed with macroalgae. Thalassodendron ciliatum is the dominant seagrass in the bay, often forming monospecific meadows extending to the reef.

There are two major tidal creeks (Kidogoweni and Kinondo) draining the upper region dominated by mangrove vegetation, which are inundated during high tide and dry up during low tide. It is a shallow water system with mean depths often less than $5 \mathrm{~m}$, with a channel approximately $4 \mathrm{~km}$ long fringed by $\sim 6.6 \mathrm{~km}^{2}$ of mangrove forest mainly composed of Sonneratia alba, Rhizophora mucronata, Ceriops tagal, Bruguiera gymnorrhiza, Avicennia marina, Xylocarpus granatum and Lumnitzera racemosa, S. alba and $R$. mucronata are the dominant mangrove species (Kimani et al., 1996). The channel remains inundated throughout the tidal regimes. The total area of the bay excluding areas covered by 


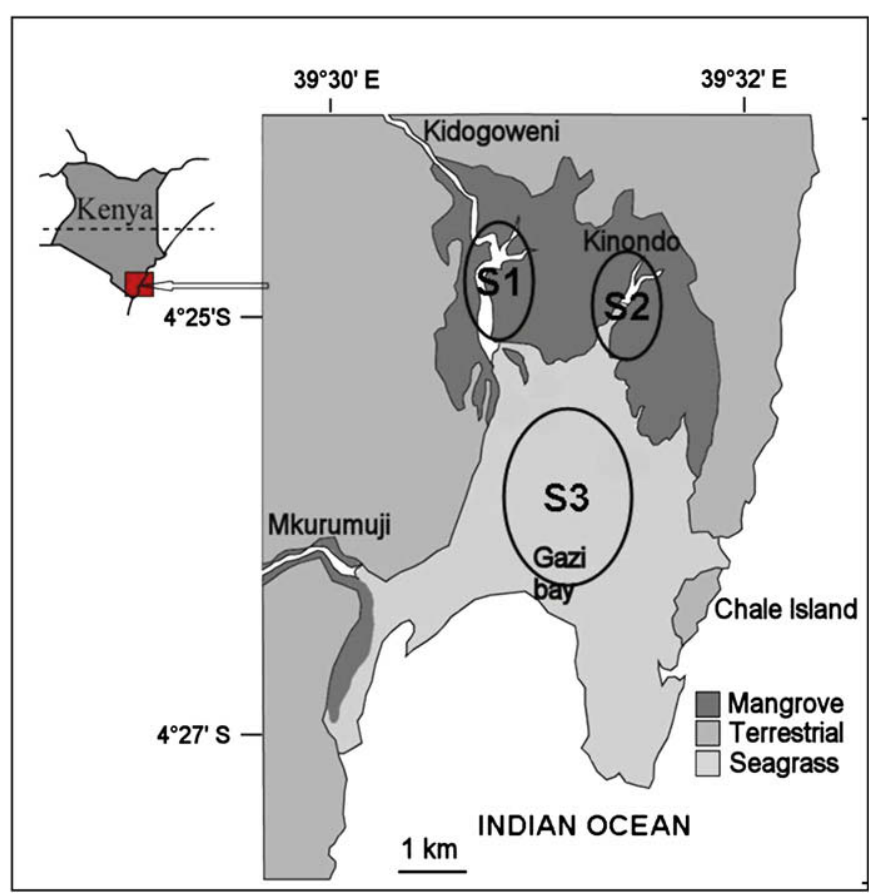

Fig. 1. Map of Gazi Bay, Kenya. S1 and S2 indicate sampling locations in the mangrove sites, $\mathrm{S} 3$ refers to sampling area in the seagrass beds.

mangroves is $10 \mathrm{~km}^{2}$. The bay receives freshwater through the Kidogoweni river which is turbid during the rainy season (March to October) but a slow-moving clear stream during the dry season (November to February) (Kimani et al., 1996). On the south-western part of the bay, there are additional freshwater inputs through the River Mkurumuji. The bay has a semi-diurnal tide regime with amplitude varying between $2.9 \mathrm{~m}$ at spring tide and $0.7 \mathrm{~m}$ at neap tide (Hemminga et al., 1994). The area is influenced by two monsoon regimes: the North-East monsoon from November to March and the South-East monsoon from May to September.

\subsection{Sample collection}

Sample collections were carried out between October 2004 and December 2005, which represented both the dry and wet seasons in the study area. Various fish species, mangroves, seagrass, macroalgae, epiphytes, suspended particulate organic matter (SPOM) and sediment organic matter (SOM) were collected for isotopic analysis. Fish samples represented various trophic functional groups, while the other samples represented potential carbon sources. Samples were collected from several sites with different vicinity to the mangrove forest (Fig. 1). Sites S1 and S2 were located in the tidal creeks flowing through extensive mangrove forests, while site S3 was located in the subtidal seagrass meadows located far from the fringe mangrove forest. Fish sampling was done with a $45 \mathrm{~m}$ long, $2 \mathrm{~m}$ wide beach seine net with a $20 \mathrm{~mm}$ stretch mesh size; in combination with a $20 \mathrm{~m}$ long gill net with $30 \mathrm{~mm}$ stretch mesh size. Sampling was done to target as many fish species as possible found in the bay. A total of 42 fish species and 2 crustacean species were collected for analysis. In addition, samples for macroinvertebrates were collected from the mangrove and seagrass sites and processed for isotopic analysis.

Fresh leaves from 7 mangrove species were collected from sites 1 and 2. These included: Avicennia marina, Bruguiera gymnorrhiza, Ceriops tagal, Lumnitzera racemosa, Rhizophora mucronata, Sonneratia alba and Xylocarpus granatum. Seagrass leaves were collected from 8 common seagrass species (Thalassodendron ciliatum,
Cymodocea rotunda, Cymodocea serrulata, Cymodostera sp., Enhalus acroides, Halodule uninervis, Halophila stipulacea, and Syringodium isoetifolium). Macroalgae species collected within the seagrass beds were Ceratodictyon spongium, Cystoseira trinodis, Dictyota sp., Gracilaria corticata, Gracilaria saloicornia, Hypnea cornata, Sargassum sp., Turbinaria decudrens, Ulva partusa, and U. reticulata. Seagrass epiphytes consisting mainly of fine filamentous algae were obtained by scraping them off with a scalpel from properly rinsed seagrass leaves upon return in the laboratory.

Water samples for analysis of suspended particulate organic matter were collected from the surface using $5 \mathrm{~L}$ plastic bottles. Sediment samples for SOM were collected using $6 \mathrm{~cm}$ diameter cores, whereby the top $1 \mathrm{~cm}$ layer was sliced off and stored in plastic bags. All samples were stored on ice and transported to the laboratory for further processing.

\subsection{Sample processing}

All specimens were thoroughly rinsed with tap water. Fish were identified to species level and classified according to different trophic functional groups based on Smith and Heemstra (1991) and Froese and Pauly (2007). These trophic groups included: carnivores (fish and invertebrate feeders), carnivores (invertebrate feeders), omnivores and herbivores. In addition, fish gut content analysis was performed for some species to confirm their trophic status (data not discussed). Dorsal muscle tissue from fish specimens was carefully processed as described by Pinnegar and Polunin (1999), while abdominal muscle tissues were removed from the crustacean species (Portunus pelagicus and Pseudopenaeus indicus). Fish muscle tissue was used because it reflects the food that has been assimilated over longer period of time (within 3-4 weeks) due to its slow turnover rate (Gearing, 1991). Seagrass and macroalgae samples were sorted according to species and any visible meiofauna, macrofauna or detritus removed. All samples were oven-dried at $60^{\circ} \mathrm{C}$ for $24 \mathrm{~h}$, and finally ground to a fine powder using a mortar and pestle. The powdered samples were weighed according to sample type ( $\sim 1 \mathrm{mg}$ for fauna and flora; $\sim 15 \mathrm{mg}$ for sediment) and placed in clean silver cups (pre-combusted at $450{ }^{\circ} \mathrm{C}$ ) for stable isotope analysis. Where contamination with $\mathrm{CaCO}_{3}$ was likely, samples were treated with $5 \% \mathrm{HCl}$ in the silver cups to remove carbonates and re-dried (Nieuwenhuize et al., 1994).

Water samples for SPOM were pre-filtered through a $200 \mu \mathrm{m}$ mesh to remove detritus and zooplankton. $4 \mathrm{~L}$ of water was then filtered through pre-combusted $\left(4 \mathrm{~h}\right.$ at $500^{\circ} \mathrm{C}$ ) Whatman $\mathrm{GF} / \mathrm{F}$ filters $(0.7 \mu \mathrm{m}$ nominal pore-size) under moderate vacuum $(-10 \mathrm{mbar})$. The filters were also dried at $60^{\circ} \mathrm{C}$ for $24 \mathrm{~h}$. They were acidified with $\mathrm{HCl}$ fumes under partial vacuum for $1 \mathrm{~h}$ and re-dried prior to analysis (Lorrain et al., 2003).

\subsection{Stable isotope analysis}

Samples for stable isotope analysis were analysed with a Thermo Flash1112 Elemental Analyzer coupled to a Thermo Delta $+\mathrm{XL}$ isotope ratio mass spectrometer. Carbon and nitrogen isotope ratios were expressed in the conventional delta notation $\left(\delta^{13} \mathrm{C}\right.$, $\delta^{15} \mathrm{~N}$ ) relative to standard reference materials (V-PDB for $\delta^{13} \mathrm{C}$, and atmospheric $\mathrm{N}_{2}$ for $\delta^{15} \mathrm{~N}$ ), and the results were expressed as:

$\left.\delta X=\left[\left(R_{\text {sample }} / R_{\text {standard }}\right)-1\right]\right] \times 1000$

Where $X$ is either ${ }^{13} \mathrm{C}$ or ${ }^{15} \mathrm{~N}$ and $R$ is the ratio of the heavy to the light isotope. The average reproducibility for $\delta^{13} \mathrm{C}$ and $\delta^{15} \mathrm{~N}$ values based on replicate measurements on samples was better than $0.2 \%$. 


\subsection{Statistical analysis}

The sampling stations were treated as units representing mangrove habitats and seagrass habitats. Seasonal variation in stable isotope data for all samples, and differences between isotopic signatures of fish from mangrove and seagrass sites were tested using the Mann-Whitney $U$ test. Since we did not observe any differences between the dry and wet season in the stable isotope signatures for all compartments, $\delta^{13} \mathrm{C}$ and $\delta^{15} \mathrm{~N}$ data for consumers and producers from each site were pooled to represent each habitat. The data were tested for normality using the ShapiroWilks $W$ test for normality. In case data were not normally distributed, they were $\log 10$-transformed and tested again for normality. Since in most cases the data were not normally distributed, Kruskal-Wallis ANOVA was used to test for differences in $\delta^{13} \mathrm{C}$ and $\delta^{15} \mathrm{~N}$ between different fish trophic groups and between different autotrophs.

\section{Results}

\subsection{Stable isotope ratios of autotrophs, SOM and SPOM}

The primary organic carbon sources included 7 species of mangroves, 8 species of seagrass, 10 species of macroalgae and

\section{Table 1}

Stable carbon and nitrogen isotope signatures (average \pm 1 s.d.) of primary carbon sources, SPOM and SOM in Gazi bay. Numbers of samples are in parenthesis. $\left(^{*}\right)$ : Isotope signatures for microphytobenthos from mangrove habitats obtained from Bouillon et al. (2004a).

\begin{tabular}{|c|c|c|c|}
\hline Species & Site & $\delta^{13} \mathrm{C}(\%)$ & $\delta^{15} \mathrm{~N}(\%)$ \\
\hline \multicolumn{4}{|l|}{ Mangroves } \\
\hline Avicennia marina (3) & 1,2 & $-29.3 \pm 1.0$ & $5.0 \pm 2.4$ \\
\hline Bruguiera gymnorrhiza (1) & 1 & -28.7 & 2.1 \\
\hline Ceriops tagal (1) & 1 & -26.4 & 5.1 \\
\hline Lumnitzera racemosa (1) & 1 & -27.5 & 0.5 \\
\hline Rhizophora mucronata (3) & 1,2 & $-27.8 \pm 0.2$ & $6.8 \pm 1.9$ \\
\hline Sonneratia alba (3) & 1,2 & $-26.7 \pm 0.8$ & $3.8 \pm 2.5$ \\
\hline Xylocarpus granatum (3) & 1 & $-26.0 \pm 0.7$ & $1.73 \pm 1.9$ \\
\hline Overall average & & $-27.7 \pm 1.4$ & $4.4 \pm 2.6$ \\
\hline \multicolumn{4}{|l|}{ Seagrass } \\
\hline Cymodocea rotunda (1) & 2 & -18.4 & 0.9 \\
\hline Cymodocea serrulata (3) & 2 & $-18.4 \pm 1.1$ & $0.2 \pm 0.1$ \\
\hline Cymodostera sp. (3) & 2,3 & $-15.1 \pm 2.2$ & $0.2 \pm 0.4$ \\
\hline Enhalus acroides (3) & 2 & $-13.57 \pm 2.9$ & $1.43 \pm 1.2$ \\
\hline Halodule uninervis (1) & 1 & -16.3 & 1.4 \\
\hline Halophila stipulacea (3) & 3 & $-11.9 \pm 0.8$ & $1.1 \pm 0.6$ \\
\hline Syringodium isoetifolium (3) & 3 & $-19.4 \pm 0.8$ & $2.4 \pm 1.3$ \\
\hline Thalassodendron ciliatum (3) & 2,3 & $-15.9 \pm 0.4$ & $1.5 \pm 0.3$ \\
\hline Overall average & & $-15.1 \pm 3.0$ & $1.2 \pm 1.3$ \\
\hline Epiphytes (8) & 2,3 & $-13.6 \pm 3.3$ & $6.6 \pm 3.1$ \\
\hline Microphytobenthos* & & $-23.8 \pm 0.1$ & $1.9 \pm 0.1$ \\
\hline \multicolumn{4}{|l|}{ Macroalgae } \\
\hline Ceratodictyon spongium (1) & 2 & -20.6 & 0.5 \\
\hline Cystoseira trinodis (1) & 3 & -14.2 & 3.9 \\
\hline Dictyota sp. (1) & 2 & -24.8 & 2.3 \\
\hline Gracilaria sp. (2) & 2 & $-22.3 \pm 0.1$ & $3.5 \pm 0.2$ \\
\hline Hypnea cornata (1) & 1 & -22.7 & 3.4 \\
\hline Sargassum sp. (1) & 2 & -27.5 & 2.5 \\
\hline Sargassum sp. (2) & 3 & $-18.1 \pm 0.6$ & $1.2 \pm 0.9$ \\
\hline Turbinaria decudrens (1) & 2 & -15.4 & 2.2 \\
\hline Ulva partusa (1) & 2 & -22.1 & 0.9 \\
\hline Ulva reticulate (1) & 2 & -26.7 & 2.5 \\
\hline Overall average & & $-20.4 \pm 3.1$ & $2.4 \pm 1.2$ \\
\hline \multicolumn{4}{|l|}{ Others (mixed sources) } \\
\hline $\begin{array}{l}\text { Suspended particulate organic matter } \\
\quad \text { (SPOM) (24) }\end{array}$ & $1,2,3$ & $-19.3 \pm 2.8$ & $6.2 \pm 3.0$ \\
\hline $\begin{array}{l}\text { Surface sediment organic matter } \\
\text { (SOM) (39) }\end{array}$ & $1,2,3$ & $-23.2 \pm 2.6$ & $2.3 \pm 1.5$ \\
\hline
\end{tabular}

seagrass epiphytes, which likely included a mixture of diatoms, encrusting algae and filamentous algae (Vizzini et al., 2002). $\delta^{13} \mathrm{C}$ and $\delta^{15} \mathrm{~N}$ values of potential carbon sources showed a high variability (Table 1). There were significant differences in $\delta^{13} \mathrm{C}$ and $\delta^{15} \mathrm{~N}$ values among all potential carbon sources (Kruskal-Wallis test; $P<0.001)$. Mangrove $\delta{ }^{13} \mathrm{C}$ was the most ${ }^{13} \mathrm{C}$-depleted available sources $(-27.7 \pm 1.4 \%)$, while seagrasses $(-15.1 \pm 3.0 \%)$ and seagrass epiphytes $(-13.6 \pm 3.3 \%)$ were relatively ${ }^{13} \mathrm{C}$-enriched. Intermediate $\delta^{13} \mathrm{C}$ values were observed in macroalgae $(-20.4 \pm 3.1 \%$ oo. Data for microphytobenthos (MPB) from the intertidal mangrove forest in the study area (Bouillon et al., 2004a), were quite depleted and are thus likely not to be representative for MPB in the seagrass beds. There was clear spatial variability in $\delta^{13} \mathrm{C}$ for submerged primary producers, with those from mangrove sites having relatively depleted values compared to those collected from the seagrass sites (Fig. 2).

Other organic matter pools representing mixtures of other autotrophic sources were SOM (range, $-26.3 \%$ to $-17.2 \%$; average, $-23.2 \%$ ), and SPOM (range, $-24.7 \%$ to $-12.8 \%$; average, $-19.3 \%$ ). There was a clear spatial trend in SOM, showing more depleted $\delta^{13} \mathrm{C}$ values within the mangrove sites $(-24.5 \pm 1.3 \%$ ) compared to the seagrass sites $(-20.2 \pm 2.2 \%$ ) (Fig. 2). In contrast, no distinct difference was observed for SPOM from both sites, because these samples were collected during various tidal stages, thereby confounding the spatial trend in $\delta^{13} \mathrm{C}$ of SPOM observed earlier in this system (Hemminga et al., 1994; Bouillon et al., 2007).

$\delta^{15} \mathrm{~N}$ values within and between the groups of organic matter sources were also quite variable ranging from an average of $6.6 \pm 3.1 \%$ for seagrass epiphytes to $1.2 \pm 1.0 \%$ for seagrass tissue. Other sources and organic carbon pools showed intermediate $\delta^{15} \mathrm{~N}$ values, i.e. $6.2 \pm 3.0 \%$ for SPOM, $4.4 \pm 2.6 \%$ for mangroves, $2.4 \pm 1.2 \%$ for macroalgae, $2.3 \pm 1.5 \%$ for SOM, and $1.9 \pm 0.1 \%$ for MPB (Table 1).

\subsection{Stable isotope ratios of consumers}

Carbon and nitrogen isotope signatures for all fishes and crustaceans sampled from Gazi Bay are summarized in Table 2. There was a wide range in consumer $\delta^{13} \mathrm{C}$ values, varying from $-21.5 \%$ for Siganus sutor to $-10.5 \%$ for Trachinotus blochii. In addition, average $\delta^{13} \mathrm{C}$ ratios significantly differed between the postulated 4 trophic functional groups (Kruskal-Wallis ANOVA; $P<0.001$ ). Within each trophic group, there was wide variation in $\delta^{13} \mathrm{C}$ values (Table 2 ). In relation to habitat use, 3 separate groups of fishes were identified

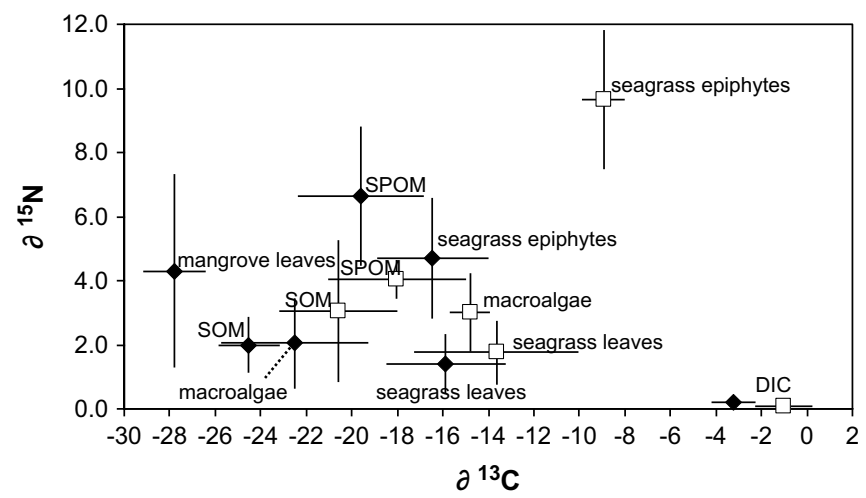

Fig. 2. Plot of $\delta^{13} \mathrm{C}$ and $\delta^{15} \mathrm{~N}$ (average \pm 1 s.d.) showing spatial variation for different primary producers, suspended particulate organic matter (SPOM), sediment organic matter (SOM), and dissolved inorganic carbon (DIC). $\bullet$ - samples from the mangrove creek sites (S1 and S2). $\square$ - samples from seagrass beds in the open bay (S3). $\delta^{13} \mathrm{C}$ values for DIC (own unpublished data). 
Table 2

Carbon and nitrogen stable isotope signatures (average \pm 1 s.d.) for fish species collected from mangrove (S1, S2) and seagrass (S3) habitats. Fish marked $\left(^{g}\right)$ were grouped depending on gut content analysis. Numbers of samples are in parenthesis. Trophic modes are: C: carnivores; O: omnivores; H: herbivores. Typical food sources mentioned between brackets are indicated as fi (fish), iv (benthic invertebrates), zp (zooplankton), pl (plant material), pp (phytoplankton), and dt (detritus).

\begin{tabular}{|c|c|c|c|c|}
\hline $\begin{array}{l}\text { Carnivores (fish \& invertebrate } \\
\text { feeders) }\end{array}$ & Site & Trophic mode & $\delta^{13} \mathrm{C}(\% \mathrm{o})$ & $\delta^{15} \mathrm{~N}(\%)$ \\
\hline Lutjanus argentimaculatus (1) & 2 & C (fi/iv/zp) & -20.0 & 9.3 \\
\hline Lutjanus fulviflamma ${ }^{g}(5)$ & 1 & C (fi/iv/zp) & $-18.2 \pm 0.1$ & $10.2 \pm 0.1$ \\
\hline Lutjanus fulviflamma ${ }^{\mathrm{g}}(23)$ & 3 & & $-14.2 \pm 1.8$ & $10.0 \pm 0.6$ \\
\hline Plotosus lineatus ${ }^{g}(8)$ & 2 & C (fi/iv) & $-18.0 \pm 1.0$ & $8.3 \pm 0.6$ \\
\hline Lethrinus harak ${ }^{\mathrm{g}}(6)$ & 1,2 & $C(f i / z p)$ & $-18.4 \pm 0.7$ & $8.2 \pm 0.4$ \\
\hline Lethrinus harak ${ }^{\mathrm{g}}(4)$ & 3 & $C(f i / z p)$ & $-15.5 \pm 0.6$ & $8.6 \pm 0.1$ \\
\hline Synodus variegatus (1) & 1 & $C(f i)$ & -19.0 & 10.6 \\
\hline Synodus variegatus (4) & 3 & & $-16.9 \pm 0.9$ & $9.5 \pm 0.5$ \\
\hline Cheilodipterus quinquelineatus ${ }^{\mathrm{g}}(1)$ & 1 & C (fi/iv/zp) & -15.2 & 9.6 \\
\hline Pterois volitans (1) & 2 & $C($ fi/iv/zp) & -17.4 & 9.6 \\
\hline Fistularia petimba (1) & 2 & $\mathrm{C}(\mathrm{fi} / \mathrm{zp})$ & -17.2 & 10.8 \\
\hline Sphyraena barracuda ${ }^{\mathrm{g}}(9)$ & 2 & $C(f i)$ & $-16.6 \pm 0.9$ & $10.1 \pm 0.6$ \\
\hline Gymnothorax meleagris (1) & 2 & $C(\mathrm{fi} / \mathrm{zp})$ & -16.3 & 8.5 \\
\hline Saurida undosquamis (2) & 2 & $C($ fi/iv/zp) & $-16.0 \pm 0.5$ & $9.2 \pm 0.5$ \\
\hline Tylosurus crocodilus ${ }^{g}(6)$ & 1,2 & $C($ fi/iv/zp) & $-16.0 \pm 1.1$ & $10.5 \pm 0.7$ \\
\hline Lethrinus nebulosus ${ }^{\mathrm{g}}(6)$ & 1,2 & $C(f i / z p)$ & $-15.2 \pm 1.3$ & $8.7 \pm 0.2$ \\
\hline Taeniura lymna (1) & 3 & $C(f i / i v)$ & -13.8 & 11.8 \\
\hline Overall average & 1-3 & & $-16.9 \pm 1.5$ & $9.3 \pm 1.1$ \\
\hline \multicolumn{5}{|l|}{ Carnivores (invertebrate feeders) } \\
\hline Sphaeramia orbicularis (8) & 1,3 & C (iv) & $-19.2 \pm 2.1$ & $8.6 \pm 0.6$ \\
\hline Periophthalmus sobrinus (1) & 1 & C (iv) & -19.1 & 8.5 \\
\hline Gerres oyena ${ }^{g}(1)$ & 1 & C (iv) & -17.4 & 8.4 \\
\hline Pelates quadrilineatus ${ }^{\mathrm{g}}(4)$ & 1 & C (iv) & $-14.9 \pm 1.8$ & $8.0 \pm 0.2$ \\
\hline Neopomacentrus fuliginosus (1) & 2 & $C(z p)$ & -19.5 & 9.6 \\
\hline Fowleria aurita (1) & 2 & $C$ (iv) & -17 & 7.6 \\
\hline Archamia fucata (13) & 2 & C (iv) & $-15.7 \pm 0.6$ & $9.6 \pm 0.4$ \\
\hline Portunus pelagicus (Crustacea) (1) & 2 & C (iv) & -15.3 & 7.6 \\
\hline Penaeus indicus (Crustacea) (1) & 2 & C (iv) & -15 & 8.5 \\
\hline Parupeneus barberinus (5) & 1,2 & $C(\mathrm{iv} / \mathrm{zp})$ & $-15.8 \pm 0.3$ & $8.2 \pm 0.7$ \\
\hline Upeneus tragula (5) & 3 & $C$ (iv) & $-16.7 \pm 0.5$ & $8.7 \pm 0.6$ \\
\hline Diodon sp. (1) & 3 & C (iv) & -15.9 & 8.8 \\
\hline Pteragogus flagellifer (4) & 3 & C (iv) & $-15.5 \pm 0.5$ & $8.4 \pm 0.2$ \\
\hline Stethojulis strigiventer (3) & 3 & C (iv) & $-14.9 \pm 0.5$ & $8.7 \pm 0.3$ \\
\hline Callionymus marleyi (10) & 3 & $C$ (iv) & $-14.6 \pm 0.5$ & $7.6 \pm 0.3$ \\
\hline Parascorpaena mossambica (1) & 3 & $C$ (iv) & -13.9 & 6.5 \\
\hline Bothus pantherinus (1) & 3 & C (iv) & -13.7 & 8.2 \\
\hline Paramonacanthus barnadi (1) & 3 & C (iv & -13.6 & 6.8 \\
\hline Trachinotus blochii (5) & 3 & $C(\mathrm{iv} / \mathrm{zp})$ & $-10.5 \pm 0.2$ & $8.7 \pm 0.3$ \\
\hline Overall average & 1-3 & & $-15.1 \pm 1.9$ & $8.6 \pm 0.8$ \\
\hline \multicolumn{5}{|l|}{ Omnivores } \\
\hline Valamugil seheli (6) & 1,3 & $\mathrm{O}(\mathrm{iv} / \mathrm{pt} / \mathrm{dt})$ & $-19.4 \pm 0.4$ & $6.0 \pm 0.2$ \\
\hline Mugil cephalus (4) & 1 & $\mathrm{O}$ (iv/zp/pp/dt) & $-13.1 \pm 0.4$ & $5.1 \pm 0.5$ \\
\hline Hemiramphus far (1) & 2 & $\mathrm{O}(\mathrm{fi} / \mathrm{zp} / \mathrm{pt})$ & -20 & 8.9 \\
\hline Monodactylus argenteus (1) & 2 & $\mathrm{O}$ (iv/zp/dt) & -18.2 & 8.9 \\
\hline Hemiramphus brasiliensis (1) & 2 & $\mathrm{O}(\mathrm{fi} / \mathrm{pt})$ & -15.2 & 9.1 \\
\hline Amblygobius phalaena ${ }^{\mathrm{g}}(4)$ & 2 & $\mathrm{O}$ (iv/pt/dt) & $-16.4 \pm 0.4$ & $6.1 \pm 0.5$ \\
\hline Sardinella melanura (2) & 3 & $\mathrm{O}(\mathrm{zp} / \mathrm{pp})$ & $-17.4 \pm 0.4$ & $9.4 \pm 0.1$ \\
\hline Dascyllus aruanus (1) & 3 & $\mathrm{O}(\mathrm{fi} / \mathrm{zp} / \mathrm{pt})$ & -16.4 & 10.3 \\
\hline Amblygobius phalaena ${ }^{\mathrm{g}}(3)$ & 3 & $\mathrm{O}$ (iv/pt/dt) & $-14.0 \pm 0.2$ & $6.1 \pm 0.1$ \\
\hline Sillago sihama (5) & 3 & $\mathrm{O}$ (iv/pt/dt) & $-14.9 \pm 0.5$ & $8.6 \pm 0.4$ \\
\hline Arothron hispidus (1) & 3 & $\mathrm{O}$ (iv/pt/dt) & -14.7 & 7.6 \\
\hline Dascyllus trimaculatus (1) & 3 & $\mathrm{O}$ (iv/zp/pt) & -14.6 & 10.5 \\
\hline Overall average & 1-3 & & $-15.3 \pm 1.8$ & $7.6 \pm 1.8$ \\
\hline \multicolumn{5}{|l|}{ Herbivores } \\
\hline Siganus sutor ${ }^{g}(6)$ & 2 & $\mathrm{H}$ & $-21.5 \pm 1.2$ & $6.6 \pm 0.2$ \\
\hline Siganus sutor ${ }^{g}(24)$ & 3 & $\mathrm{H}$ & $-16.1 \pm 1.7$ & $7.6 \pm 0.4$ \\
\hline Siganus fuscescens ${ }^{g}(4)$ & 2 & $\mathrm{H}$ & $-17.8 \pm 0.2$ & $7.7 \pm 0.2$ \\
\hline Leptoscarus vaigiensis ${ }^{g}(3)$ & 2 & $\mathrm{H}$ & $-16.1 \pm 0.9$ & $6.1 \pm 1.2$ \\
\hline Leptoscarus vaigiensis ${ }^{g}(7)$ & 3 & $\mathrm{H}$ & $-14.0 \pm 0.7$ & $5.5 \pm 0.3$ \\
\hline Overall average & 2,3 & & $-17.0 \pm 3.1$ & $6.6 \pm 1.1$ \\
\hline
\end{tabular}

based on $\delta^{13} \mathrm{C}$ values (Fig. 3a and b). These included: (1) species with highly depleted $\delta^{13} \mathrm{C}$ values (i.e. Periophthalmus sobrinus, Neopomacentrus fuliginosus, Sphaeramia orbicularis, Lutjanus argentimaculatus, S. sutor, Valamugil seheli and Hemiramphus far);
(2) majority of species with intermediate $\delta^{13} \mathrm{C}$ values ranging between $-18 \%$ and $-12 \%$; and (3) one species with highly enriched $\delta^{13} \mathrm{C}$ values (T. blochii). Generally, herbivores had the most depleted $\delta{ }^{13} \mathrm{C}$ value with an average of $-17.0 \pm 3.1 \%$ (Table 2 ).

The overall average for all fish species examined was $-16.0 \pm 2.1 \%$ o yet $\delta^{13} \mathrm{C}$ and $\delta^{15} \mathrm{~N}$ signatures of fish from mangrove and seagrass habitats were significantly different (Mann-Whitney $U$ test; $P<0.05$ ) (Table 3). Differences in $\delta^{13} \mathrm{C}$ for all examined fishes were most pronounced and were lower in the mangroves $(-16.8 \pm 2.0 \%)$ than in the seagrass beds $(-14.7 \pm 1.7 \%)$. There were significant differences in $\delta^{13} \mathrm{C}$ for herbivores and invertebrate feeders collected from the mangrove and seagrass habitats (MannWhitney $U$ test; $P<0.05$ ) (Table 3 ). Similar differences were found at the species level, with $\delta^{13} \mathrm{C}$ values of 4 species occurring in both habitats (Leptoscarus vaigiensis, Amblygobius phalaena, Lethrinus harak and Siganus sutor) being depleted in $\delta^{13} \mathrm{C}$ by approximately $2.4-6.6 \%$ in the mangrove habitat as compared to those in the seagrass habitat (Table 3 ).

Stable nitrogen ratios, indicative of trophic levels, ranged from $5.1 \%$ for Mugil cephalus to $11.8 \%$ for Taeniura lymna (Table 2 ), with an overall average of $8.4 \pm 1.4 \%$. There were significant differences in $\delta^{15} \mathrm{~N}$ values between the 4 trophic functional groups (Kruskal-Wallis ANOVA; $P<0.001)$. Herbivores had the lowest average $\delta^{15} \mathrm{~N}$ value of $6.6 \pm 1.1 \%$, while carnivores feeding on fish and invertebrates had the highest value of $9.3 \pm 1.1 \%$ Other trophic functional groups had values ranging between $7.6 \pm 1.8 \%$ for omnivores, and $8.6 \pm 0.8 \%$ for carnivorous invertebrate feeders (Table 2). Three major groups were identified based on $\delta^{15} \mathrm{~N}$ values (Fig. 3a and b). These were:

(1) Species with very low $\delta^{15} \mathrm{~N}$ value represented by Mugil cephalus (Fig. 3b);

(2) Species with intermediate values (Paramonacanthus barnadi, Parascorpaena mossambica, Leptoscarus vaigiensis, Siganus sutor, Amblygobius phalaena and Valamugil seheli); and

(3) Species with high values $\left(\delta^{15} \mathrm{~N}>10 \%\right.$ ) represented by most fishes feeding on fishes and/or invertebrates. This included: predatory piscivores such as Taeniura lymna, Fistularia petimba, Tylosurus crocodilus, Lutjanus fulviflamma and Sphyraena barracuda; and the omnivores Dascyllus trimaculatus and Dascyllus aruanus. Overall, $\delta^{15} \mathrm{~N}$ was relatively higher for fishes from the mangrove habitat (Mann-Whitney $U$ test; $P<0.05$ ), with the exception of omnivorous fishes (Table 3). For carnivores feeding on fish and invertebrates, no differences were observed in $\delta^{15} \mathrm{~N}$ between the two habitats.

\section{Discussion}

\subsection{Stable isotopic ratios of autotrophs, and composition of SPOM and SOM}

The isotopic signatures of potential organic carbon sources supporting the food web in Gazi Bay exhibited wide variation in $\delta^{13} \mathrm{C}$. Based on the $\delta^{13} \mathrm{C}$ values, four distinct groups were observed among the primary carbon sources which include: (1) mangroves; (2) microphytobenthos; (3) macroalgae; and (4) seagrass epiphytes and seagrass (Fig. 4). $\delta^{13} \mathrm{C}$ signatures of mangroves and seagrasses were within the range reported earlier for Gazi Bay (Hemminga et al., 1994; Rao et al., 1994; Bouillon et al., 2004b). There was clear spatial variation in $\delta^{13} \mathrm{C}$ of macroalgae, seagrass and seagrass epiphytes in the bay (Fig. 2), determined largely by variation in $\delta^{13} \mathrm{C}$ of dissolved inorganic carbon (DIC). In our case, macroalgae, seagrass and seagrass epiphytes collected adjacent to the mangrove forests areas were ${ }^{13} \mathrm{C}$-depleted relative to those in the central part of the bay, consistent with the inputs of ${ }^{13} \mathrm{C}$-depleted inorganic carbon 

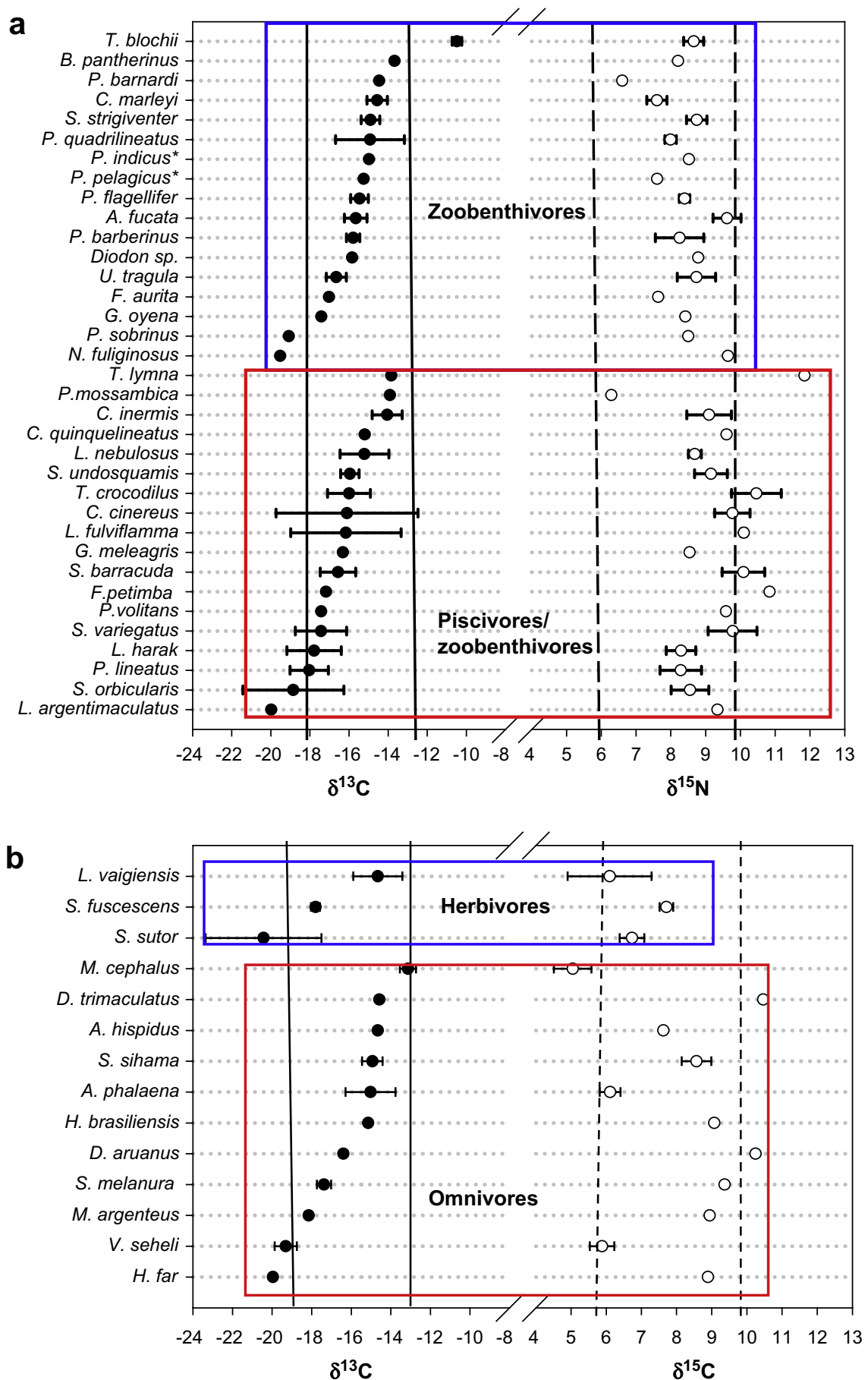

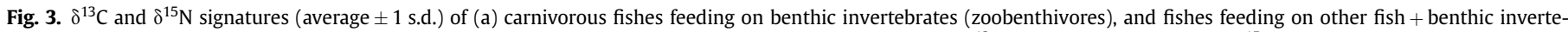

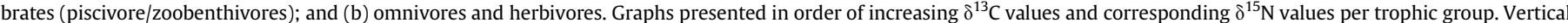

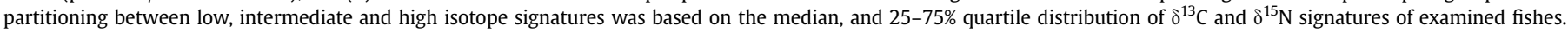

through the tidal creeks (Bouillon et al., 2007). The $\delta^{13} C_{\text {DIC }}$ values collected at our sites during the same sampling campaigns ranged between $-4.3 \%$ and $+0.5 \%$, and are within the range observed in a more intensive sampling transect throughout the creeks and bay (Bouillon et al., 2007).

The $\delta^{13} \mathrm{C}$ for SPOM in the entire bay was quite homogeneous, ranging between -19.9 and $-18.0 \%$ as a result of tidal flushing and mixing in the bay. Low phytoplankton biomass and high POC/Chl $a$ ratios (764 \pm 259$)$ have been reported in Gazi Bay (Bouillon et al., 2007), which indicates that phytoplankton biomass makes an insignificant contribution to the SPOM pool. Therefore, SPOM was likely to be a mixture of various degraded organic carbon sources mainly derived from macroalgae and seagrasses, and to a lesser extent re-suspended microphytobenthos. Our results also corroborates well with findings in south Australian gulfs showing that SPOM was composed of material with enriched carbon isotope values presumed to originate from seagrass or epiphytic algae (Connolly et al., 2005).

Sediment organic matter showed a spatial trend, with relatively depleted average $\delta^{13} \mathrm{C}$ values in the mangrove sites compared to the 
Table 3

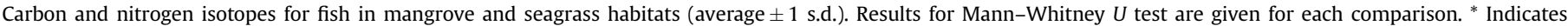
significant differences at $\mathrm{P}<0.005$.

\begin{tabular}{|c|c|c|c|c|c|c|}
\hline \multirow[t]{2}{*}{ Trophic groups } & \multicolumn{3}{|l|}{$\delta^{13} \mathrm{C}(\%)$} & \multicolumn{3}{|l|}{$\delta^{15} \mathrm{~N}(\%)$} \\
\hline & Mangrove sites & Seagrass sites & $P$ & Mangrove sites & Seagrass sites & $P$ \\
\hline Carnivores (fish/invertebrates) & $-17.0 \pm 1.5$ & $-15.9 \pm 1.4$ & 0.1521 & $9.2 \pm 1.0$ & $9.6 \pm 1.2$ & 0.3902 \\
\hline Carnivores (invertebrates) & $-15.9 \pm 1.3$ & $-14.3 \pm 2.0$ & $0.0019 *$ & $8.9 \pm 0.9$ & $8.2 \pm 0.6$ & $0.0056^{*}$ \\
\hline Omnivores & $-15.5 \pm 2.4$ & $-15.2 \pm 1.3$ & 0.8678 & $6.5 \pm 1.8$ & $8.2 \pm 1.5$ & $0.0350^{*}$ \\
\hline Herbivores & $-18.9 \pm 2.5$ & $-14.1 \pm 0.7$ & $0.0002^{*}$ & $7.2 \pm 0.8$ & $5.8 \pm 0.7$ & $0.0020^{*}$ \\
\hline All examined fishes & $-16.8 \pm 2.0$ & $-14.7 \pm 1.7$ & $0.0000^{*}$ & $8.6 \pm 1.4$ & $8.0 \pm 1.4$ & $0.0133^{*}$ \\
\hline \multicolumn{7}{|l|}{ Fish species } \\
\hline Siganus sutor & $-21.5 \pm 1.2$ & $-16.1 \pm 1.7$ & $0.0428^{*}$ & $6.6 \pm 0.2$ & $7.6 \pm 0.4$ & 0.1213 \\
\hline Lethrinus harak & $-18.4 \pm 0.7$ & $-15.5 \pm 0.6$ & $0.0367^{*}$ & $8.2 \pm 0.4$ & $8.6 \pm 0.1$ & 0.1171 \\
\hline Leptoscarus vaigiensis & $-16.1 \pm 0.9$ & $-14.0 \pm 0.7$ & $0.0167^{*}$ & $6.1 \pm 1.2$ & $5.5 \pm 0.3$ & 0.0527 \\
\hline Amblygobius phalaena & $-16.4 \pm 0.4$ & $-14.0 \pm 0.2$ & $0.0338^{*}$ & $6.1 \pm 0.5$ & $6.1 \pm 0.1$ & 0.4795 \\
\hline
\end{tabular}

seagrass sites (Fig. 2). This observation illustrates the localized contribution of the dominant primary producers to the sedimentary pool at each site, with a high contribution of mangrove carbon in the sediment close to the fringe mangrove forest, and a mixture of seagrass, macroalgae and mangrove-derived carbon in the seagrass sites. However, the observed overall intermediate $\delta^{13} \mathrm{C}$ values of SOM in the entire bay are attributed to constant mixing and deposition of outwelled organic carbon from the mangrove forest with that in the seagrass beds. Evidence show that part of ${ }^{13} \mathrm{C}$ depleted carbon exported from the mangroves of Gazi Bay leaves the system as SPOM and is trapped within the seagrass zone (Hemminga et al., 1994). This exported mangrove carbon comprised $\sim 20-70 \%$ of sediment organic carbon in the seagrass beds (Bouillon et al., 2004a).

\subsection{Organic carbon sources supporting fish communities}

A wide variation in $\delta^{13} \mathrm{C}$ for fishes within each trophic group clearly portrays that fishes obtain their diet from various sources,

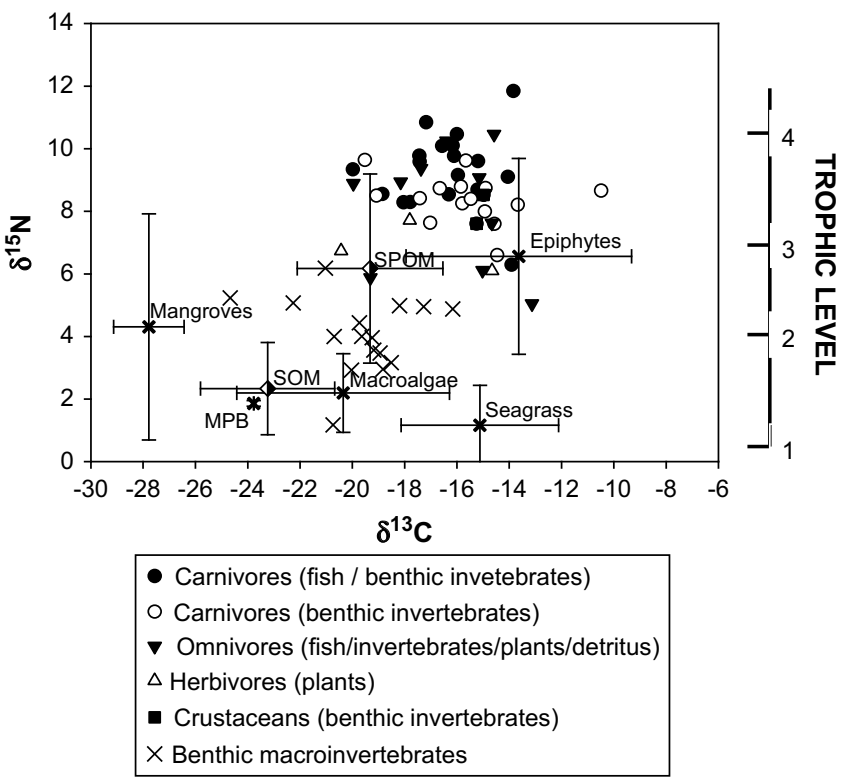

Fig. 4. Scatter plot of average ( \pm 1 s.d.) $\delta^{13} \mathrm{C}$ and $\delta^{15} \mathrm{~N}$ for organic carbon sources, benthic macroinvertebrates and different fish trophic groups from pooled samples from all sites. In parenthesis are the main food items for the investigated fishes and crustaceans. Trophic level estimates using $\delta^{15} \mathrm{~N}$ whereby, a $3.4 \%$ increase in ${ }^{15} \mathrm{~N}$ equals an increase of one trophic level. Isotope signatures for microphytobenthos from mangrove habitats obtained from Bouillon et al. (2004a). Macroinvertebrate data (own unpublished data). regardless of their trophic groupings. The average $\delta^{13} \mathrm{C}$ for mangroves $(-27.7 \%$ ) was much more depleted compared to those of fishes, indicating a very limited contribution of mangrove carbon to fish diet, consistent with most other similar studies (Marguillier et al., 1997; Nagelkerken and van der Velde, 2004b; Lugendo et al., 2006).

Carbon isotope signatures of most fishes were within the range observed for seagrasses and seagrass epiphytes (Fig. 4). A number of fish species from the mangrove habitats exhibited low $\delta^{13} \mathrm{C}$ $(<-19 \%)$. Since these values are more negative than those found in seagrasses and epiphytes in this habitat, this indicates that mangrove or macroalgae-derived organic matter contributed to their diet, either directly or indirectly. These included: the carnivores Periophthalmus sobrinus, Neopomacentrus fuliginosus, Sphaeramia orbicularis and Lutjanus argentimaculatus; the omnivores Valamugil seheli and Hemiramphus far; and the herbivore Siganus sutor (Table 2, Fig. 3). These species thus derived their food by feeding either selectively on macroalgae (e.g., in the case of the herbivore $S$. sutor) or on invertebrates which in turn were depending to a certain extent on macroalgae or mangrove-derived matter. Gut contents for $S$. sutor revealed the presence of macroalgae, while the similarity in $\delta^{13} \mathrm{C}$ values of $S$. sutor $(-21.5 \pm 1.2 \%$ ) from the mangrove sites with those of macroalgae $(-20.4 \pm 4.1 \%)$ confirm the contribution by macroalgae to this species' diet.

For another herbivorous species, Leptoscarus vaigiensis, gut content data showed a significant contribution by seagrass material, which is consistent with the similar $\delta^{13} \mathrm{C}$ signatures found in L. vaigiensis $(-14.7 \pm 1.2 \%)$ and seagrasses $(-15.1 \pm 3.0 \%)$. Direct utilization of seagrass material has sometimes been suggested to be minimal, but recent evidence suggests that this may need to be reconsidered. Prado et al. (2007), for example, found that a high proportion of leaf production in a Mediterranean seagrass bed was lost through herbivory by fish and sea urchins. Generally, our observations are consistent with those in other studies in the subtropical seagrass beds in Australia showing that seagrasses and seagrass epiphytes were the dominant source of nutrition for most consumers (Moncreiff and Sullivan, 2001; Connolly et al., 2005). Whereas assimilation of seagrass carbon by larval fish, has been demonstrated in waters offshore of Tasmania, Australia (Thresher et al., 1992).

Pathways of organic matter transfer from primary producers to higher trophic levels are explained by relating carbon and nitrogen isotope values of the primary producers, benthic invertebrates and zoobenthivorous fishes. Our results showed general enrichment in ${ }^{15} \mathrm{~N}$ with increasing trophic level across various groups. Primary producers were at the base, macroinvertebrates at intermediary level and most fishes at the top of the food web (Fig. 4). Because $\delta^{15} \mathrm{~N}$ has widely been used as a trophic level indicator, the gradient in $\delta^{15} \mathrm{~N}$ among all compartments in the bay portrays the pathway of 
energy transfer from primary producers to macroinvertebrates and eventually to the fish community. The distribution of $\delta^{13} \mathrm{C}$ values for benthic macroinvertebrates shows that most macroinvertebrate taxa examined in this study rely substantially on macroalgae, and to a lesser extent on seagrass and seagrass epiphytes as their carbon source (Fig. 4). Other mixed organic carbon matter such as SPOMSOM pool is also important in supporting food webs in this ecosystem, through utilization by detritivores and filter feeding invertebrates. Consumption of benthic macroinvertebrates by fishes and crabs inhabiting seagrass meadows (Connolly et al., 2005), provides a means of transferring carbon from primary producers to the fish community through a set of predator-prey interactions known as trophic relay (Kneib, 2000).

\subsection{Feeding habitats}

Mangrove ecosystems are widely known to provide suitable feeding habitats for fish. Overall results from pooled samples indicate that $\delta^{13} \mathrm{C}$ for fish collected from the mangrove channels were significantly depleted compared to those from the seagrass beds. Since $\delta^{13} \mathrm{C}$ of consumers reflects that of their diet, this consistent difference in $\delta^{13} \mathrm{C}$ for fishes collected from the two habitats indicates that mangrove and seagrass beds acted as distinct feeding zones. $\delta^{13} \mathrm{C}$ results on pooled data for fishes from the entire bay (Fig. 3) show that the fish community can be distinguished into 3 groups in relation to their preferred habitats. These include: a few species characterized by depleted $\delta^{13} \mathrm{C}$ $(<-18 \%)$, which are likely restricted to the mangrove habitats. A second group (including the majority of the species) which either utilize the seagrass beds only and occasionally move to sites closer to the mangroves; and lastly species that could be associated with the coral reef due to their highly enriched $\delta^{13} \mathrm{C}$ value, and occasionally move into the shallow intertidal areas. Kimani et al. (1996) observed short-term feeding migrations of some reef fishes into the shallow mangrove-seagrass habitats in Gazi Bay, which represent connectivity and energy transfer between these distinct habitats. Shuttle movement of fish between the mangrove areas, seagrass beds and the open waters in the coral reef due to tidal variations have also been reported (Marguillier et al., 1997). Despite these movements, spatial differences in $\delta^{13} \mathrm{C}$ for fishes collected within the vicinity of mangroves and those from the seagrass beds indicate that most of the fishes were specific in using either of these habitats as feeding grounds.

Moreover, considering that stable isotope ratios of aquatic organisms reflect that of available food sources, and the gradient in $\delta^{13} \mathrm{C}$ of examined fishes is of the same magnitude as that observed in primary producers. Our results therefore suggest that these fishes utilized these habitats as feeding grounds.

At the species level, a similar trend was observed whereby Leptoscarus vaigiensis, Siganus sutor, Lethrinus harak and Amblygobius phalaena from the mangrove channel had depleted $\delta^{13} \mathrm{C}$ values compared to individuals of the same species obtained from the seagrass beds (Table 3 ). Comparing only the herbivorous species (L. vaigiensis and $S$. sutor), results indicate a small difference of $\sim 2.4 \%$ between individuals of $L$. vaigiensis collected from the mangrove site and those from the seagrass bed; indicating that this species exclusively feeds in the seagrass beds. In contrast, a large difference in $\delta^{13} \mathrm{C}$ of $\sim 6.6 \%$ between individuals of $S$. sutor collected from the two habitats suggests the possibility of some fish feeding in the mangrove and others in the seagrass beds. Although individuals of $S$. sutor, L. harak and A. phalaena examined were within the same size range, the spatial differences in $\delta^{13} \mathrm{C}$ probably indicate presence of different subpopulations: one that shelter and feed within the mangrove and adjacent habitats, and the other that shelter and feed exclusively in the seagrass beds. Similarly,
Nagelkerken and van der Velde (2004a) concluded that partial separation in feeding habitat of individuals of the same species of coral reef fishes could be attributed to the existence of two subpopulations. However we suggest that to maximize on the profitability of using these habitats, fish may integrate the feeding and sheltering value of these interconnected ecosystems.

\section{Conclusions}

Our study demonstrates the relative importance of various primary producers as organic matter sources supporting the diverse fish community in Gazi Bay. All biotic components in Gazi bay showed distinct carbon isotope signatures, with mangroves being the most depleted in $\delta^{13} \mathrm{C}$ compared to seagrasses, epiphytes and macroalgae. The $\delta^{13} \mathrm{C}$ for most of the fishes examined was within the range observed for seagrasses, epiphytes and macroalgae. This evidence supports the feeding hypothesis in contiguous mangrove-seagrass ecosystems, while indicating that mangrove detritus is not substantially important in food chains supporting fishery. Seagrasses, their associated epiphytic organisms and to a lesser extent macroalgae are the most important organic matter sources in the bay, with the latter being quite significant in the diet of certain herbivorous species (e.g., Siganus sutor).

Most fishes were suggested to feed in the area where they were caught, implying localized habitat utilization for both feeding and sheltering. Regular migration of fish between the mangrove and seagrass habitats as a result of daily tidal fluctuations does not necessarily result into transfer of energy or exchange of material. Due to the ecological importance, and biological connectivity between mangroves and seagrass ecosystems, integrated management of the two systems is necessary to ensure maintenance of coastal fisheries.

\section{Acknowledgements}

We are thankful to H. Kirauni and D. Odongo for assistance with fieldwork. Dr. J. Kazungu, the Director of Kenya Marine and Fisheries Research Institute provided logistical support and research facilities. F. Dehairs provided access to the IRMS facilities. This study was financially supported by the Kenya-Belgium VLIR-IUC-UoN Project implemented at the University of Nairobi, Kenya, and Vrije Universiteit Brussels, Belgium. The constructive comments of two anonymous referees greatly improved this manuscript. This is publication number XXXX of the Netherlands Institute of Ecology (NIOO-KNAW).

\section{References}

Baran, E., Hambrey, J., 1998. Mangrove conservation and coastal management in southeast Asia: what impact on fishery resources? Marine Pollution Bulletin 37, 431-440.

Blaber, S.J.M., 2007. Mangroves and fishes: issues of diversity, dependence and dogma. Bulletin of Marine Science 80, 457-472.

Bouillon, S., Moens, T., Dehairs, F., 2004a. Carbon sources supporting benthic mineralization in mangrove and adjacent seagrass sediments (Gazi Bay, Kenya). Biogeosciences 1, 71-78.

Bouillon, S., Moens, T., Overmeer, I., Koedam, N., Dehairs, F., 2004b. Resource utilization patterns of epifauna from mangrove forests with contrasting inputs of local versus imported organic matter. Marine Ecology Progress Series 278, 77-88.

Bouillon, S., Dehairs, F., Velimirov, B., Abril, G., Borges, A.V., 2007. Dynamics of organic and inorganic carbon across contiguous mangrove and seagrass systems (Gazi bay, Kenya). Journal of Geophysical Research 112, G02018, doi:10.1029/2006JG000325.

Bouillon, S., Connolly, R., Lee, S.Y., 2008. Organic matter exchange and cycling in mangrove ecosystems: recent insights from stable isotope studies. Journal of Sea Research 59, 44-58.

Chong, V.C., Sasekumar, A., Leh, M.U.C., D’Cruza, R., 1990. The fish and prawn communities of a Malaysian coastal mangrove system, with comparisons to 
adjacent mud flats and inshore waters. Estuarine, Coastal and Shelf Science 31, 703-722.

Connolly, R.M., Hindell, J.S., Gorman, D., 2005. Seagrass and epiphytic algae support nutrition of a fisheries species, Sillago schomburgkii, in adjacent intertidal habitats. Marine Ecology Progress Series 286, 69-79.

De Troch, M., Mees, J., Papadopoulos, I., Wakwabi, E.O., 1996. Fish communities in a tropical bay (Gazi Bay, Kenya): seagrass versus unvegetated areas. Netherlands Journal of Zoology 46, 236-252.

Deegan, L.A., Garritt, R.H., 1997. Evidence for spatial variability in estuarine food webs. Marine Ecology Progress Series 147, 31-47.

Duarte, C.M., Cebrian, J., 1996. The fate of marine autotrophic production. Limnology and Oceanography $41,1758-1766$.

Froese, R., Pauly, D. (Eds.), 2007. FishBase. World Wide Web Electronic Publication. www.fishbase.org version (10/2007).

Fry, B., Sherr, E.B., 1984. Delta ${ }^{13} \mathrm{C}$ measurements as indicators of carbon flow in marine and fresh-water ecosystems. Contributions in Marine Science 27, 13-47.

Gearing, J.N., 1991. The study of diet and trophic relationships through natural abundance of 13-C. In: Coleman, D.C., Fry, B. (Eds.), Carbon Isotope Techniques. Academic Press, London, pp. 201-218.

Guelinckx, J., Maes, J., Van Den Driessche, P., Geysen, B., Dehairs, F., Ollevier, F., 2007. Changes in $\delta^{13} \mathrm{C}$ and $\delta^{15} \mathrm{~N}$ in different tissues of juvenile sand goby Pomatoschistus minutus: a laboratory diet-switch experiment. Marine Ecology Progress Series 341, 205-215.

Hedges, J.I., Keil, R.G., Benner, R., 1997. What happens to terrestrial organic matter in the ocean? Organic Geochemistry 27, 192-212.

Hemminga, M.A., Slim, F.J., Kazungu, J., Ganssen, G.M., Nieuwenhuize, J., Kruyt, N.M., 1994. Carbon outwelling from a mangrove forest with adjacent seagrass beds and coral-reefs (Gazi Bay, Kenya). Marine Ecology Progress Series 106, 291-301.

Hobson, K.A., Welch, H.E., 1992. Determination of trophic relationships within a high arctic marine food web using delta-C-13 and delta-N-15 analysis. Marine Ecology Progress Series 84, 9-18.

Hobson, K.A., Clark, R.G., 1992. Assessing avian diets using stable isotopes 1: turnover of ${ }^{13} \mathrm{C}$ in tissue. Condor 94, 181-188.

Kimani, E.N., Mwatha, G.K., Wakwabi, E.O., Ntiba, J.M., Okoth, B.K., 1996. Fishes of a shallow tropical mangrove estuary, Gazi, Kenya. Marine and Freshwater Research 47, 857-868.

Kneib, R.T., 2000. Saltmarsh ecoscapes and production transfers by estuarine nekton in the southeastern United States. In: Weinstein, M.P., Kreeger, D.A (Eds.), Concepts and Controversies in Tidal Marsh Ecology. Kluwer Academic Dordrecht, pp. 267-292.

Lee, S.Y., 1995. Mangrove outwelling - a review. Hydrobiologia 295, 203-212.

Lorrain, A., Savoye, N., Chauvaud, L., Paulet, Y.-P., Naulet, N., 2003. Decarbonation and preservation method for the analysis of organic $\mathrm{C}$ and $\mathrm{N}$ contents and stable isotopes of low-carbonated suspended particulate material. Analytica Chimica Acta 491, 125-133.

Logan, J., Haas, H., Deegan, L., Gaines, E., 2006. Turnover rates of nitrogen stable isotopes in the salt marsh mummichog, Fundulus heteroclitus, following a laboratory diet switch. Oecologia 147, 391-395.

Lugendo, B.R., Nagelkerken, I., van der Velde, G., Mgaya, Y.D., 2006. The importance of mangroves, mud and sand flats, and seagrass beds as feeding areas for juvenile fishes in Chwaka Bay, Zanzibar: gut content and stable isotope analyses. Journal of Fish Biology 69, 1639-1661.

Lugendo, B.R., Nagelkerken, I., Jiddawi, N., Mgaya, Y.D., Van Der Velde, G., 2007. Fish community composition of a tropical nonestuarine embayment in Zanzibar Tanzania. Fisheries Science 73, 1213-1223.

Marguillier, S., vanderVelde, G., Dehairs, F., Hemminga, M.A., Rajagopal, S., 1997. Trophic relationships in an interlinked mangrove-seagrass ecosystem as traced by delta C-13 and delta N-15. Marine Ecology Progress Series 151, 115-121.

McCutchan, J.H., Lewis, W.M., Kendall, C., McGrath, C.C., 2003. Variation in trophic shift for stable isotope ratios of carbon, nitrogen, and sulfur. Oikos 102, 378-390.
Meynecke, J.-O., Lee, S.Y., Warnken, J., 2007. Relationship between estuarine habitats and coastal fisheries in Queensland, Australia. Bulletin of Marine Science 80, 773-793.

Minagawa, M., Wada, E., 1984. Stepwise enrichment of N-15 along food-chains further evidence and the relation between delta-N-15 and animal age. Geochimica et Cosmochimica Acta 48, 1135-1140.

Moncreiff, C.A., Sullivan, M.J., 2001. Trophic importance of epiphytic algae in subtropical seagrass beds: evidence from multiple stable isotope analyses. Marine Ecology Progress Series 215, 93-106.

Nagelkerken, I., van der Velde, G., 2004a. Relative importance of interlinked mangroves and seagrass beds as feeding habitats for juvenile reef fish on a Caribbean island. Marine Ecology Progress Series 274, 153-159.

Nagelkerken, I., van der Velde, G., 2004b. Are Caribbean mangroves important feeding grounds for juvenile reef fish from adjacent seagrass beds? Marine Ecology Progress Series 274, 143-151.

Nagelkerken, I., Blaber, S., Bouillon, S., Green, P., Haywood, M., Kirton, L.G., Kumar, S., Meynecke, J.-O., Pawlik, J., Penrose, H., Sasekumar, A., Somerfield, P., 2008. The habitat function of mangroves for terrestrial and marine fauna: a review. Aquatic Botany 89, 155-185.

Nieuwenhuize, J., Maas, Y.E.M., Middelburg, J.J., 1994. Rapid analysis of organic carbon and nitrogen in particulate materials. Marine Chemistry 45, 217-224.

Pauly, D., Ingles, J., 1986. The Relationship Between Shrimp Yields and Intertidal Vegetation (Mangrove) Areas: a Reassessment. IOC/FAO workshop on recruitment in tropical coastal demersal communities. IOC, UNESCO, Paris, Mexico, Ciudad de Carmen, pp. 227-284.

Paw, J.N., Chua, T.E., 1989. An assessment of the ecological and economic impact of mangrove conservation in Southeast Asia. Marine Pollution Bulletin 20, 335-343.

Peterson, B.J., Fry, B., 1987. Stable isotopes in ecosystem studies. Annual Review of Ecology and Systematics 18, 293-320.

Pinnegar, J.K., Polunin, N.V.C., 1999. Differential fractionation of delta C-13 and delta $\mathrm{N}-15$ among fish tissues: implications for the study of trophic interactions. Functional Ecology 13, 225-231.

Prado, P., Tomas, F., Alcoverro, T., Romero, J., 2007. Extensive direct measurements of Posidonia oceanica defoliation confirm the importance of herbivory in temperate seagrass meadows. Marine Ecology Progress Series 340, 63-71.

Rao, R.G., Woitchik, A.F., Goeyens, L., Vanriet, A., Kazungu, J., Dehairs, F., 1994 Carbon, nitrogen contents and stable carbon isotope abundance in mangrove leaves from an East African coastal lagoon (Kenya). Aquatic Botany 47, 175-183.

Sheaves, M., 2005. The nature and consequences of biological connectivity in mangrove systems. Marine Ecology Progress Series 302, 293-305.

Smith, M.M., Heemstra, P.C., 1991. Smith's Sea Fishes, first ed. Southern Book Publishers, Johannesburg.

Sogard, S.M., 1992. Variability in growth rates of juvenile fishes in different estuarine habitats. Marine Ecology Progress Series 85, 35-53.

Thresher, R.E., Nichols, P.D., Gunn, J.S., Bruce, B.D., Furlani, D.M., 1992. Seagrass detritus as the basis of a coastal planktonic food-chain. Limnology and Oceanography 37, 1754-1758.

Tieszen, L.L., Boutton, T.W., Tesdahl, K.G., Slade, N.A., 1983. Fractionation and turnover of stable carbon isotopes in animal tissues: implications for $\delta^{13} \mathrm{C}$ analysis of diet. Oecologia 57, 32-37.

Vander Zanden, M.J., Rasmussen, J.B., 2001. Variation in delta N-15 and delta C-13 trophic fractionation: implications for aquatic food web studies. Limnology and Oceanography 46, 2061-2066.

Vanderklift, M.A., Ponsard, S., 2003. Sources of variation in consumer-diet delta N-15 enrichment: a meta-analysis. Oecologia 136, 169-182.

Vizzini, S., Sara, G., Michener, R.H., Mazzola, A., 2002. The role and contribution of the seagrass Posidonia oceanica (L.) Delile organic matter for secondary consumers as revealed by carbon and nitrogen stable isotope analysis. Acta Oecologica 23, 277-285. 